\title{
A prospective study of clinical and diagnostic methods of ovarian tumors admitted in a tertiary care hospital and its correlation with histopathology
}

\author{
Silika Madria1, Vineeta Ghanghoriya ${ }^{1 *}$, Kavita N. Singh ${ }^{1}$, Manisha Lokwani ${ }^{2}$, Ranu Tiwari ${ }^{3}$ \\ ${ }^{1}$ Department of Obstetrics and Gynecology, Netaji Subhash Chandra Bose Medical College, Jabalpur, Madhya Pradesh, \\ India \\ ${ }^{2}$ Department of Radiodiagnosis, Netaji Subhash Chandra Bose Medical College, Jabalpur, Madhya Pradesh, India
}

Received: 16 October 2021

Accepted: 01 November 2021

*Correspondence:

Dr. Vineeta Ghanghoriya,

E-mail: sunil.madria27@gmail.com

Copyright: (C) the author(s), publisher and licensee Medip Academy. This is an open-access article distributed under the terms of the Creative Commons Attribution Non-Commercial License, which permits unrestricted non-commercial use, distribution, and reproduction in any medium, provided the original work is properly cited.

\section{ABSTRACT}

Background: Aim of the study was to study demographic profile and diagnostic modalities of ovarian tumors and their correlation with histopathological report (HPR).

Methods: Prospective observational study conducted in NSCB medical college, Jabalpur from February 2019 to July 2020 on subjects with ultrasonographically diagnosed ovarian tumors. Relevant history obtained, gynecologic examination, investigations recorded. Subjects followed up to collection of HPR and correlation with histopathology done.

Results: Out of 120 cases of ovarian tumors, $39.16 \%$ were malignant and $60.83 \%$ were benign ovarian tumors. Out of 80 premenopausal females, majority $(78.75 \%$ ) had benign ovarian masses. Amongst 40 postmenopausal females, $75 \%$ of ovarian masses were malignant. CA125 had sensitivity $76.59 \%$, specificity $76.71 \%$ and accuracy $76.66 \%$ in diagnosing ovarian malignancy. Amongst 4 RMI scores, RMI 1 has the highest sensitivity and specificity $85.10 \%$, $86.30 \%$ respectively. Sensitivity, specificity, and accuracy of ultrasound score was $65.21 \%, 86.30 \%$ and $77.5 \%$ respectively. Sensitivity and specificity of clinical diagnosis was $83 \%$ and $95.89 \%$ respectively and ROC analysis showed clinical diagnosis can accurately predict benign and malignant ovarian tumors in $89 \%$ cases.

Conclusions: RMI 1 score has the highest sensitivity and specificity in our study. When all 4 methods of diagnosis i.e., RMI Score, ultrasound score, CA125 and clinical diagnosis were compared, clinical diagnosis has highest prediction of malignancy.

Keywords: Ovarian cancer, CA 125, Ultrasound score, RMI score

\section{INTRODUCTION}

Ovarian malignancy is the most common gynecological cancer in females after breast and cervical carcinoma and second most common cancer of the female reproductive system and the leading cause of the death from gynecologic malignancy in India as well as worldwide and unfortunately it remains clinically silent until advanced stage. $^{1,3}$ Rate of malignancy is up to $60 \%$ in postmenopausal women and $24 \%$ in premenopausal women. $^{2}$

Indian trend analysis showed a steady increase in the agestandardized incidence rate of ovarian cancer ranging from $0.26 \%$ to $2.44 \%$ per year. ${ }^{4}$ The overall 5 -years survival is $45 \%$ primarily because of the late stage at diagnosis of the disease. ${ }^{5}$ By the time the disease becomes symptomatic, the stage of the cancer would have been stage III or IV 
and even aggressive treatment is associated with treatment failure and recurrence. ${ }^{6}$ Most of these cancers $(>80 \%)$ are epithelial in nature and among epithelial tumors, most common variety is serous cystadenocarinoma. ${ }^{7}$ This tumor secretes a tumor antigen known as CA 125 which can be used as a marker for screening and follow up of women with ovarian malignancy. ${ }^{8}$

Many scoring systems for prediction of ovarian malignancy include CA 125 values in their tumor prediction algorithms, for example, RMI scoring, ROMA index, OVA1 etc. Novel serum biomarkers for detection of ovarian tumors are HE4, mesothelin, prostasin, kallikreins, lysophosphatidic acid, OVX1 and osteopontin. Aggressive debulking surgery, followed by platinum-based chemotherapy, usually results in clinical remission. But, up to 80 percent of these women will develop a relapse that leads to disease progression and death. Newer treatment modalities are bevasizumab and PARP inhibitors. Histomorphological features with radiological, clinical, and other ancillary investigations including tumor markers hold keys for early diagnosis. The purpose of this study is to study the accuracy of diagnostic modalities for ovarian tumors in central India.

\section{Objectives}

Objectives of the study was to study demographic profile, diagnostic modalities of ovarian tumors and their correlation with HPR.

\section{METHODS}

The study was prospective observation study. The study conducted at Netaji Subhash Chandra Bose medical college, Jabalpur, Madhya Pradesh, India from February 2019 to July 2020.

\section{Inclusion criteria}

All subjects with ultrasonographical diagnosis of ovarian tumors were included.

\section{Exclusion criteria}

Pelvic masses other than ovarian tumors, functional, inflammatory, and metaplastic ovarian cyst were excluded.

\section{Procedure}

Admitted subjects presenting with ovarian tumors on ultrasonography were evaluated according to relevant history, high risk factors for ovarian tumors and demographic characteristics. Clinical evaluation, gynecological examination, ultrasonography, biochemical profile and other relevant investigations were done for the subjects. Surgical staging was done in cases with operable malignant ovarian tumors. Subjects followed up upto collection of histopathological report.

\section{Ethical approval}

Ethical approval taken by institutional ethical committee, Netaji Subhash Chandra Bose medical college, Jabalpur (M.P.)

\section{Statistical analysis}

Compiled data was statistically analyses using Chi square test and/or Fischer's exact test to compare $2 \times 2$ contingency distribution as appropriate and ROC analysis was performed to predict benign and malignant ovarian tumors. $\mathrm{P}<0.05$ was considered statistically significant. All statistical calculations were done with SPSS statistics version 20.0 .

\section{RESULTS}

Total 120 cases of sonographically confirmed ovarian tumors were studied. The $39.16 \%$ were malignant and $60.83 \%$ were benign neoplasm (Table 1). Maximum number of cases of benign tumors were in age group 3140 years and that of malignant ovarian tumors were of 41 50 years age group (Table 1). Present study shows no correlation of ovarian malignancy with parity of females, locality, and regularity of menstrual cycle (Table 1). Out of 80 premenopausal females, majority (78.75\%) had benign ovarian masses and only $21.25 \%$ had malignant ovarian masses. While amongst 40 postmenopausal females, $75 \%$ of the ovarian masses were malignant and $25 \%$ were benign (Table 1). With standard cut-off value of $35 \mathrm{U} / \mathrm{ml}, \mathrm{CA} 125$ had sensitivity of $76.59 \%$, specificity of $76.71 \%$, accuracy of $76.66 \%$ and positive predictive value $67.92 \%$ in diagnosing ovarian malignancy (Table 2). Sensitivity, specificity and accuracy of ultrasound score with a cut off of 3 was $65.21 \%, 86.30 \%$ and $77.5 \%$ respectively (Table 3 ). In our study, ultrasound diagnosis using gray scale and color doppler has sensitivity and specificity of $80.90 \%$ and $87.70 \%$ for malignant ovarian tumors respectively (Table 4). Amongst 4 RMI scores, RMI 1 has the highest sensitivity and specificity $85.10 \%$, $86.30 \%$ while RMI 2 had comparable specificity $85.30 \%$ but lower sensitivity $63.82 \%$ than RMI 1, RMI 3 has comparable specificity $(83.56 \%)$ but less sensitivity $(59.57 \%)$ and accuracy $(74.16 \%)$ than RMI 1 score. RMI 4 is least specific $(82.19 \%)$. The positive predictive value as well as the negative predictive value are highest for RMI $1,80 \%$ and $90 \%$ respectively thus highest accuracy is of RMI $1(85.83 \%)$ (Table 5). RMI 1 has the highest specificity, sensitivity, positive and negative predictive value (Table 6).

In our study clinical diagnosis with thorough preoperative assessment of patients including bimanual pelvic examination, radiological evaluation and CA 125 measurement has highest ability to predict benign and malignant ovarian tumors when compared with gold standard of diagnosis i.e., histopathologic examination (Figure 1). 


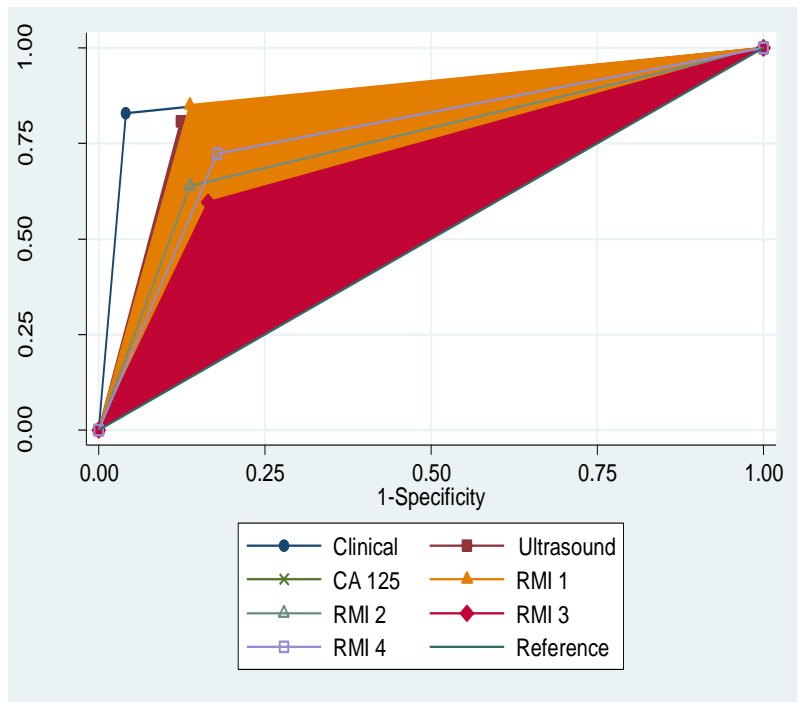

Figure 1: Receiver operating curve (ROC) analysis in prediction of benign and malignant ovarian tumors.

Table 1: Patient characteristics.

\begin{tabular}{|c|c|c|c|}
\hline \multirow{2}{*}{$\begin{array}{l}\text { Number of } \\
\text { patients }\end{array}$} & $\begin{array}{l}\text { Benign } \\
(\%)\end{array}$ & $\begin{array}{l}\text { Malignant } \\
(\%)\end{array}$ & P value \\
\hline & $\begin{array}{l}73 \\
(60.83)\end{array}$ & $\begin{array}{l}47 \\
(39.16)\end{array}$ & 0.0008 \\
\hline $\begin{array}{l}\text { Mean age } \\
\text { (Years) }\end{array}$ & 35.5 & 45.5 & $<0.0001$ \\
\hline Locality & $\begin{array}{l}\text { Rural-53 } \\
(58.24) \\
\text { Urban-20 } \\
(68.96)\end{array}$ & $\begin{array}{l}\text { Rural-38 } \\
(41.75) \\
\text { Urban-9 } \\
(31.03)\end{array}$ & 0.302 \\
\hline Parity & $\begin{array}{l}\text { Nulliparous } \\
-21(65.62) \\
\text { Primiparous } \\
-9(65.28) \\
\text { Multiparous } \\
-43(58.10)\end{array}$ & $\begin{array}{l}\text { Nulliparous } \\
-11 \text { (34.37) } \\
\text { Primiparous } \\
-5(35.71) \\
\text { Multiparous } \\
-31(41.89)\end{array}$ & 0.737 \\
\hline $\begin{array}{l}\text { Menopausal } \\
\text { status at } \\
\text { diagnosis }\end{array}$ & $\begin{array}{l}\text { Pre- } \\
\text { menopausal } \\
-63(78.75) \\
\text { Post- } \\
\text { menopausal } \\
-10(25)\end{array}$ & $\begin{array}{l}\text { Pre- } \\
\text { menopausal } \\
-17(21.25) \\
\text { Post- } \\
\text { menopausal } \\
-30(75)\end{array}$ & $<0.0001$ \\
\hline
\end{tabular}

Table 2: Distribution of cases based on serum CA125.

\begin{tabular}{|c|c|c|c|}
\hline $\begin{array}{l}\text { Serum } \\
\text { CA } 125\end{array}$ & $\begin{array}{l}\text { Benign, } \\
\text { no. }(\%)\end{array}$ & $\begin{array}{l}\text { Malignant, } \\
\text { no. }(\%)\end{array}$ & $\begin{array}{l}\text { Total, no. } \\
(\%)\end{array}$ \\
\hline$<35 \mathrm{u} / \mathrm{ml}$ & $56(76.71)$ & $11(23.40)$ & $67(55.83)$ \\
\hline$>35 \mathrm{u} / \mathrm{ml}$ & $17(23.28)$ & $36(76.5)$ & $53(44.1)$ \\
\hline Total & $73(100)$ & $47(100)$ & $120(100)$ \\
\hline
\end{tabular}

$76.66 \%$ and positive predictive value $67.92 \%$ in diagnosing ovarian malignancy.

Table 3: Distribution of cases based on Lerner's ultrasound score.

\begin{tabular}{|llll|}
\hline $\begin{array}{l}\text { Lerner's } \\
\text { ultrasound } \\
\text { score }\end{array}$ & $\begin{array}{l}\text { Benign, } \\
\text { no. }(\%)\end{array}$ & $\begin{array}{l}\text { Malignant, } \\
\text { no. }(\%)\end{array}$ & $\begin{array}{l}\text { Total, } \\
\text { no. }(\%)\end{array}$ \\
\hline$<3$ & 63 & 17 & 80 \\
& $(86.30)$ & $(36.10)$ & $(66.66)$ \\
\hline \multirow{2}{*3}{} & 10 & 30 & 40 \\
& $(13.69)$ & $(63.82)$ & $(33.33)$ \\
\hline \multirow{2}{*}{ Total } & 73 & 47 & 120 \\
\hline
\end{tabular}

Chi square $=32.33 ; \mathrm{p}<0.0001$

Sensitivity, specificity and accuracy of ultrasound score with a cut off of 3 was $65.21 \%, 86.30 \%$ and $77.5 \%$ respectively.

Table 4: Ultrasound diagnosis verses histopathological report for ovarian tumors.

\begin{tabular}{|llll|}
\hline $\begin{array}{l}\text { Ultrasound } \\
\text { diagnosis } \\
\text { (Using Gray } \\
\text { scale and color } \\
\text { doppler) }\end{array}$ & Benign & Malignant & Total \\
\hline Benign & 64 & 9 & 73 \\
\hline Malignant & 9 & 38 & 47 \\
\hline Total & 73 & 47 & 120 \\
\hline
\end{tabular}

Chi square $=56.344 ; \mathrm{p}<0.0001$

In our study, ultrasound diagnosis using gray scale and color doppler has sensitivity and specificity of $80.90 \%$ and $87.70 \%$ for malignant ovarian tumors respectively.

Table 5: Distribution of cases based on RMI scores.

\begin{tabular}{|llll|}
\hline $\begin{array}{l}\text { RMI } \\
\text { score }\end{array}$ & $\begin{array}{l}\text { Benign } \\
(\%)\end{array}$ & $\begin{array}{l}\text { Malignant } \\
(\%)\end{array}$ & P value \\
\hline RMI 1 & $<200-63$ & $<200-7$ & \\
score & $>200-10$ & $(14.8)$ & $<0.0001$ \\
& $(13.6)$ & $(85.10)$ & \\
\hline & $<200-63$ & $<200-17$ & \\
RMI 2 & $(86.30)$ & $(36.17)$ & $<0.0001$ \\
Score & $>200-10$ & $>200-30$ & \\
& $(13.6)$ & $(63.8)$ & \\
& $<200-61$ & $<200-19$ & \\
RMI 3 & $(83.56)$ & $(40.42)$ & $<0.0001$ \\
Score & $>200-12$ & $>200-28$ & \\
& $(16.4)$ & $(59.57)$ & \\
\hline & $<450-60$ & $<450-12$ & \\
RMI 4 & $(82.19)$ & $(25.53)$ & $<0.0001$ \\
Score & $>450-13$ & $>450-35$ & \\
& $(17.80)$ & $(74.46)$ & \\
\hline
\end{tabular}


Table 6: Statistical parameters of serum CA 125, ultrasound score, RMI 1, RMI 2, RMI 3 and RMI 4 in study population.

\begin{tabular}{|llllll|}
\hline Parameters & Sensitivity & Specificity & PPV & NPV & Accuracy \\
\hline CA 125 & 76.59 & 76.71 & 67.92 & 83.58 & 76.66 \\
\hline Ultrasound score & 65.21 & 86.30 & 75 & 78.75 & 77.5 \\
\hline RMI 1 & 85.10 & 86.30 & 80 & 90 & 85.83 \\
\hline RMI 2 & 63.82 & 85.30 & 75 & 78.75 & 77.5 \\
\hline RMI 3 & 59.57 & 83.56 & 70 & 76.25 & 74.16 \\
\hline RMI 4 & 74.46 & 82.19 & 72.91 & 83.33 & 79.16 \\
\hline
\end{tabular}

Amongst 4 RMI scores, RMI 1 has the highest sensitivity and specificity $85.10 \%, 86.30 \%$ while RMI 2 had comparable specificity $85.30 \%$ but lower sensitivity $63.82 \%$ than RMI 1. RMI 3 has comparable specificity $(83.56 \%)$ but less sensitivity $(59.57 \%)$ and accuracy $(74.16 \%)$ than RMI 1 score. RMI 4 is least specific $(82.19 \%)$. The positive predictive value as well as the negative predictive value are highest for RMI 1, 80\% and $90 \%$ respectively thus highest accuracy is of RMI 1 $(85.83 \%)$.

RMI 1 has the highest specificity, sensitivity, positive and negative predictive value.

In our study clinical diagnosis with thorough preoperative assessment of patients including bimanual pelvic examination, radiological evaluation and CA 125 measurement has highest ability to predict benign and malignant ovarian tumors when compared with gold standard of diagnosis i.e., histopathologic examination (Figure 1).

\section{DISCUSSION}

Ovarian cancers are one of the malignancies with worst prognosis due to lack of effective screening for early detection. Proper evaluation of ovarian tumors is important because surgical intervention, if possible, can be done in time, thereby decreasing morbidity and mortality of patients. In the present study, out of 120 cases of ovarian tumors, $39.16 \%$ were malignant and $60.83 \%$ were benign neoplasms. This is comparable to the study done by Mondal et al in which benign tumors were $63.1 \%$, followed by malignant ovarian tumors (29.6\%). ${ }^{9}$ Study done by Ganga et al and Yogambal et al also found the frequency of benign and malignant tumor to be similar. ${ }^{11,12}$

Age has a strong correlation to ovarian cancer risk and advancing age increased the possibility of malignant transformation. In our study, the mean age of patient with benign ovarian tumor was 40.5 years and for malignant tumor was 45.5 year. This is comparable to findings of Radhamani et al and Bhagde et al but more than the finding of Al Shukri et al. ${ }^{10,13,14}$

Present study shows no correlation of ovarian malignancy with nulliparity or low parity of females which was consistent with the study conducted by Jindal et al. ${ }^{15}$
Out of 80 premenopausal females, $78.75 \%$ had benign ovarian masses and only $21.25 \%$ had malignant ovarian masses. While amongst 40 postmenopausal females, $75 \%$ of the ovarian masses were malignant and $25 \%$ were benign. The findings in our study are consistent with Zarchi et al. ${ }^{16}$

The standard cut off values of $35 \mathrm{U} / \mathrm{ml}$ was taken for the levels of serum CA 125 . Out of total 47 of the malignant cases, $76.5 \%$ cases have the values more than standard cut off. While amongst benign cases, $23.28 \%$ patients had values more than cut off values. So, that CA125 overall sensitivity of $76.59 \%$, specificity of $76.71 \%$, accuracy of $76.66 \%$ and positive predictive value of $67.92 \%$. It is consistent with the study by Radhamani et al which showed a sensitivity of $62.5 \%$ and specificity of $84.25 \%$ in defining the malignant nature of ovarian neoplasms. ${ }^{10}$ Mehboob et al found sensitivity of CA125 in $68 \%$ of the cases and specificity in $90 \%$. The diagnostic accuracy was $79 \%$ and a positive predictive value of $87 \% .{ }^{17}$

Cut off value of ultrasound score taken as 3, 63.82\% malignant tumors had score $>3$ While only $13.69 \%$ of benign ovarian disease had a score of more than 3 . Sensitivity, specificity and accuracy of ultrasound score in our study was $65.21 \%, 86.30 \%$ and $77.5 \%$ respectively. It was consistent with the study of Yelikar et al who concluded the sensitivity and specificity to be $80 \%$ and $83.88 \%$ respectively, and the diagnostic accuracy of $82.58 \% .^{18}$

With cut off value of RMI 1, RMI2, RMI 3 and RMI 4 taken as 200, 200, 200 and 450 respectively, values of RMI1, RMI2, RMI3 and RMI 4 calculated. Amongst these four scores, RMI 1 has the highest sensitivity and specificity $85.10 \%$ and $86.30 \%$ respectively while RMI 2 had comparable specificity $85.30 \%$ but lower sensitivity $63.82 \%$ than RMI 1. RMI 3 has comparable specificity $(83.56 \%)$ but less sensitivity $(59.57 \%)$ and accuracy (74.16\%) than RMI 1 score. RMI 4 is least specific $(82.19 \%)$. The positive predictive value as well as the negative predictive value are highest for RMI 1, $80 \%$ and $90 \%$ respectively thus highest accuracy is of RMI 1 $(85.83 \%)$ This result of our study is consistent with Agrawal et al in which RMI 1 was the most accurate tool for screening purposes with a sensitivity, specificity and accuracy of $89.93 \%, 86.11 \%$ and $85.5 \%$ respectively when compared to the gold standard of diagnosis. ${ }^{19}$ In the study 
by Kumari et al RMI-1 had the highest sensitivity and specificity. ${ }^{20}$ It had a sensitivity of $90.9 \%$, specificity 94.4\%, PPV $95.2 \%$ and NPV $89.5 \%$ in RMI 1 and sensitivity of $90.9 \%$, specificity $72.2 \%$, PPV $80 \%$ and NPV $86.7 \%$ in RMI-2.

Ultrasound has sensitivity and specificity of $80.90 \%$ and $87.70 \%$ for malignant tumors respectively. Maheshwari et al found sensitivity of $100 \%$ and $93.5 \%$ for benign and malignant tumors. ${ }^{21}$ The corresponding specificities were $93.2 \%$ and $98.3 \%$ respectively. In the study by Das ultrasonography had a sensitivity of $86.67 \%$ and specificity of $95.65 \%$ in detecting malignant ovarian masses. ${ }^{22}$

\section{Limitations}

Follow up could not be done of these patients because of limited time duration of study. In further studies, we will include the follow up. There was interobserver variability in ultrasound and clinical diagnosis of different patients in study.

\section{CONCLUSION}

In our study, clinical diagnosis with thorough preoperative assessment of patients including bimanual pelvic examination, radiological evaluation and Ca125 measurement has highest ability to predict benign and malignant ovarian tumors when compared with gold standard of diagnosis i.e., histopathological examination. Our present study concludes that clinical diagnosis combined with ultrasound findings including color doppler tumor markers and RMI score can be used to detect ovarian malignancy at an early stage and can also determine if patient can be kept on follow up, advised surgery or biopsy if the mass is unresectable and to advise chemotherapy and to detect recurrences.

\section{ACKNOWLEDGMENTS}

Author would like to thanks to my postgraduate colleagues of department for their immense support.

Funding: No funding sources

Conflict of interest: None declared

Ethical approval: The study was approved by the Institutional Ethics Committee

\section{REFERENCES}

1. Bray F, Ferlay J, Soerjomataram I, Siegel RL, Torre LA, Jemal A. Global cancer statistics 2018: GLOBOCAN estimates of incidence and mortality worldwide for 36 cancers in 185 countries. CA Cancer J Clin. 2018;68(6):394-424.

2. Singhal S, Rajoria L. Risk of malignancy index 4 in preoperative evaluation of patients with ovarian tumours. Int J Reprod Contrac Obstetr Gynecol. 2018;7(6):2467-71.
3. Jemal A, Murray T, Samuels A, Ghafoor A, Ward E, Thun MJ. Cancer statistics, 2003. CA Cancer J Clin 2003;53:5-26.

4. Murthy NS, Shalini S, Suman G, Pruthvish S, Mathew A. Changing trends in incidence of ovarian cancer, The Indian scenario. Asian Pac J Cancer Prev. 2009;10:1025-30.

5. Chen VW, Ruiz B, Killeen JL, Coté TR, Wu XC, Correa CN. Pathology and classification of ovarian tumors. Cancer. 2003;97(10)2631-42.

6. Jelovac D, Armstrong DK. Recent progress in the diagnosis and treatment of ovarian cancer. CA Cancer J Clin. 2011;61(3):183-203.

7. Cho KR, Shih IM. Ovarian cancer. Annu Rev Pathol. 2009;4:287-313.

8. Scholler N, Urban N. CA125 in ovarian cancer. Biomark Med. 2007;1(4):513-23.

9. Mondal SK, Banyopadhyay R, Nag DR, Roychowdhury S, Mondal PK, Sinha SK. Histologic pattern, bilaterality and clinical evaluation of 957 ovarian neoplasms: A 10-year study in a tertiary hospital of eastern India. J Can Res Ther. 2011;7:4337.

10. Radhamani S, Akhila MV. Evaluation of adnexal masses-correlation of clinical, sonological and histopathological findings in adnexal masses. Inter $\mathbf{J}$ Scientific Study. 2017;4(11):88-92.

11. Ganga P, Suneeta KP, Dhaded AV, Yenni VV. Ovarian tumours. JIMA. 2002:100:07.

12. Yogambal M, Arunalatha $\mathrm{P}$, Chandramouleeswari K, Palaniappan V. Ovarian tumours-incidence and distribution in a tertiary referral center in south India. IOSR-JDMS. 2014;13(2):74-80

13. Bhagde AD, Jani SK, Patel MS, Shah SR. An analytical study of 50 women presenting with an adnexal mass. Inter J Reprod Contracept Obstetr Gynecol. 2016;6(1):262-5.

14. Al-Shukri M, Mathew M, Al-Ghafri W, Al-Kalbani M, Al-Kharusi L, Gowri V. A clinicopathological study of women with adnexal masses presenting with acute symptoms. Ann Med Health Sci Res. 2014;4:286-8.

15. Jindal D. Epidemiology of epithelial ovarian cancer: a tertiary hospital-based study in Goa, India. Int $\mathbf{J}$ Reprod Contracept Obstet Gynecol. 2017;6(6):25416.

16. Karimi-Zarchi M, Mojaver SP, Teimoori S. Diagnostic Value of the Risk of Malignancy Index (RMI) for Detection of Pelvic Malignancies Compared with Pathology. Electron Physician. 2015;7(7):1505-10.

17. Mehboob S, Ghafoor F, Yunus S, Sajjad R. Role of CA-125 as an ovarian tumor marker. Pak J Med Res. 2009;48(3):23-5.

18. Yelikar KA, Deshpande SS, Nanaware SS, Pagare SB. Evaluation of the validity of risk malignancy index in clinically diagnosed ovarian masses and to compare it with the validity of individual constituent parameter of risk malignancy index. Int J Reprod Contracept Obstet Gynecol. 2016;5(2):460-4. 
19. Agrawal T, Ganguly I. To study the diagnostic role of various risks of malignancy indices (RMI 1, 2, 3, 4) in the pre-operative evaluation of adnexal masses and to compare the four RMI with each other in terms of various statistical parameters. 2015.

20. Kumari S. Risk of malignancy index for pre-operative diagnosis of ovarian cancer. Int $\mathrm{J}$ Clin Obstetr Gynaecol. 2019;3(1):128-30.

21. Maheshwari A. Accuracy of intraoperative frozen section in the diagnosis of ovarian neoplasms: experience at a tertiary oncology. World $\mathrm{J}$ surgical oncol. 2006;4(1):12.
22. Das MJ. Adnexal mass: a clinicopathological study at a tertiary care centre in Assam, India. Int J Reproduct Contrac Obstetr Gynecol. 2008;4:1458.

Cite this article as: Madria S, Ghanghoriya V, Singh KN, Lokwani M, Tiwari R. A prospective study of clinical and diagnostic methods of ovarian tumors admitted in a tertiary care hospital and its correlation with histopathology. Int J Reprod Contracept Obstet Gynecol 2021;10:4412-7. 